\title{
PARTIZANINIO MARKETINGO PRIEMONIŲ TYRIMAS
}

\author{
Margarita Išoraitė \\ Vilniaus kolegija \\ Didlaukio g. 49, 08303 Vilnius, Lietuva \\ Telefonas (+370 6) 1634648 \\ Elektroninis paštas misoraite@gmail.com
}

Pateikta 2013 m. liepos 1 d., parengta spausdinti 2013 m. lapkričio 19 d.

doi:10.13165/SMS-13-5-4-10

Anotacija. Straipsnyje analizuojami partizaninio marketingo teoriniai aspektai, nagrinejamos partizaninio marketingo priemones, tiriama respondentų nuomoné apie partizaninio marketingo priemoniu efektyvumą. Partizaninis marketingas yra taktika, prieinama kiekvienai mažai organizacijai konkuruoti su didele organizacija. Mažos organizacijos yra arčiau klientu ir laikomos aktyvesnèmis. Partizaninis marketingas reikalauja mažiau pinigu, bet pareikalauja daugiau protinio darbo. Straipsnyje pateikiami atliktų tyrimu rezultatai, kurie parode, kad didžioji dauguma respondentu partizaninį marketinga tapatina su viešuju ryšiu akcija, efektyviausiu metodu veikti vartotoju elgesį, pardavimo skatinimu, netradiciniu reklamavimo būdu, konkurenciniu pranašumu, vartotoju poreikiu tenkinimu, prekès / paslaugos žinomumo didinimu, kūrybinga reklama, reikalaujančia nedidelio biudžeto. Efektyviomis partizaninio marketingo priemonemis respondentai laiko interneta, socialinius tinklus, reklamines iškabas ir skelbimus, nemokamus seminarus, pavyzdžių dalijimą, vaizdinę reklamą laikraščiuose.

Reikšminiai žodžiai: partizaninis marketingas, virusinis marketingas, partizaninio marketingo priemonès.

Socialinių mokslų studijos / Societal Studies

(C) Mykolo Romerio universitetas, 2013

(C) Mykolas Romeris University, 2013
ISSN 2029-2236 (print), ISSN 2029-2244 (online) http://www.mruni.eu/lt/mokslo_darbai/SMS/ http://www.mruni.eu/en/mokslo_darbai/SMS/ 


\section{Ivadas}

Partizaninis marketingas dabartiniu metu yra labai sėkminga priemonè įmonèms siekiant konkurencinio pranašumo. Jis, skirtingai negu tradicinis marketingas, reikalauja daugiau laiko, energijos ir fantazijos. Daugelis partizaninio marketingo priemonių yra nemokamos. Partizaninis marketingas pripažista, kad sẻkmė pasiekiama per stiprius ryšius su klientais, teikejais, konkurentais. Taikant partizaninio marketingo strategiją Lietuvos įmonėse yra svarbu atsakyti ị klausimus: kokių pajamų jūs norite iš šios marketingo kampanijos, kokia yra jūsų tikslinė rinka, kokia yra jūsų rinkos pozicija, kokia yra pagrindinė nauda iš jūsų produkto ar paslaugų, kokius partizaninio marketingo ginklus jūs naudojate, koks yra jūsų biudžetas. Lietuvoje mokslinių publikacijų apie partizaninị marketingą vis dar pasigendama.

Temos aktualumas. Konkurencinè kova rinkoje vyksta ne tiek tarp įmonių, kiek tarp prekių ir paslaugų. Todèl kiekvienai organizacijai yra svarbu susikurti tokią nuomonę apie save, kad ji būtų visapusiškai palanki ịmonei. Nè viena įmonẻ negali būti garantuota dèl savo ateities, jeigu ji orientuojasi tik i šiandienines prekes, paslaugas ir rinkas. Imonè jaučia būtinumą turèti naujų idejų ir jas kaupti bei pasitelkti naujausias informavimo priemones. Tinkamai parengta marketingo strategija lemia įmonès plètrą, todèl klausimą, kokius lemtingus reklamos veiksmus reikètų atlikti, kad būtų galima igyvendinti reklaminès kampanijos užsibrèžtus tikslus, kelia ne viena šiuolaikinès rinkos sąlygomis veikianti immonè. Su tokiomis problemomis susiduria ir Lietuvos įmonès. Todèl naujų partizaninio marketingo priemonių taikymas Lietuvos įmonėms tampa labai svarbus.

Temos problemiškumas. Šiuolaikinèje informacinèje visuomenèje nuolatinès konkurencijos sąlygomis vis didesnę reikšmę igyja reklama, kurios pagrindiniai komponentai yra reklamos tikslų nustatymas, biudžeto sudarymas, reklaminio pranešimo kūrimas, reklamos priemonių parinkimas bei jos efektyvumo ịvertinimas. İmonè, dirbdama šiuolaikinès rinkos sąlygomis, siekdama geresnių veiklos rezultatų, privalo vykdyti efektyvią reklamos politiką, analizuojant konkurentų veiksmus bei tiriant vartotojų poreikius ir vartojimo tendencijas. Atsižvelgiant ị šiuos veiksnius, įmoné nuolatos turi tobulinti savo reklamos strategiją, t. y. efektyvumas pasiekiamas turint gerai suplanuotą marketingo strategiją. Gera marketingo strategija yra vienas iš svarbiausių faktorių norint pritraukti kuo daugiau klientų, formuoti jų poreikius ir užtikrinti, kad jie taptų nuolatiniais įmonès klientais. Kaip pažymi Išoraite் ${ }^{1}$, partizaninis marketingas - nešabloniškas marketingas, siekiant gauti maksimalius rezultatus minimaliais ištekliais. Partizaniniame marketinge, kaip teigia Levinsonas ${ }^{2}$, svarbu yra rinkos tyrimas, kuriuo siekiama „paklausti kliento“. Čia svarbus elementas yra verslo sèkmè. Faktiškai partizaninis marketingas reikalauja mažiau pinigų, bet pareikalauja daugiau protinio darbo. Šiandien partizaninio marketingo priemones naudoja tokios dideles organizacijos kaip IBM, „Microsoft“, „Volvo“,

1 Išoraite, M. Guerilla marketing strategy realization assumptions. 6th International Scientific Conference May 13-14, 2010, Vilnius, Lithuania Business and management 2010 Selected papers. Vilnius, 2010, p. 382-389. 
„American Express“ ir kitos. Mokslinių publikacijų apie reklamą autore Keršienè $\dot{e}^{3}$ labiau nagrinejja reklamą apskritai ir neišskiria netradicinès reklamos, tačiau mini efektyvios reklamos aspektus. Nuodugniau netradicinę reklamą nagrinėja Preimonas ${ }^{4}$. Kaip teigia Nu$\mathrm{fer}^{5}$, partizaninis marketingas nesistengia pakeisti klasikinio marketingo, bet siekia labiau parodyti naujas marketingo kryptis. Jis yra susijęs su inovacijomis. Caliskano ${ }^{6}$ nuomone, partizaninis marketingas yra skirtas pritraukti demesị ir siekti konkurencinio pranašumo. Tai būdas gauti pelno rinkos segmente turint mažą biudžetą ir taikant kūrybišką rinkodaros taktiką.

Tyrimo objektas - partizaninio marketingo priemonių efektyvumas.

Taigi šio straipsnio tikslas - ịvertinti VGTU studentų nuomonę apie partizaninio marketingo priemones.

Tyrimo uždaviniai:

1. Išanalizuoti partizaninio marketingo teorinius aspektus.

2. Išnagrinèti partizaninio marketingo priemones.

3. Atlikti empirinị tyrimą tikslu išsiaiškinti respondentų nuomonę apie partizanines marketingo priemones.

\section{Partizaninio marketingo teoriniai aspektai}

Partizaninis marketingas - alternatyvi marketingo forma, kuri padidina reklamos planavimo svarbą, kai klientai nuolat susiduria su klasikinio marketingo priemonèmis per televizijos kanalus, žurnalus, radiją, paštą. Partizaninis marketingas yra ideja, kuri priverčia klientus nustebti.

Partizaninio marketingo tikslas yra formuoti dinamišką, jautrų kliento poreikiams ir lengviau prisitaikantị prie pokyčių marketingą.

Terminą „partizaninis“ galima kildinti iš nepriklausomybès karų tarp Ispanijos ir Portugalijos, revoliucijų Kuboje ir Vietname. Šiuo požiūriu partizaninis marketingas yra laikomas atakos strategija, pagrịsta nustebimo efektu ir sabotažo veiksmais, kurie naudojami mažų grupių pasipriešinti masinèms karinėms pajẻgoms. 1960 metais JAV įmonès pradejjo taikyti partizaninę marketingo taktiką, kai reikejjo surasti naujų būdų būti pranašesnėms negu konkurentai. Jos atakavo silpnąsias konkurentų vietas, organizuodamos nestandartines marketingo kampanijas.

Jay Conradas Levinsonas 1983 metais terminą „partizaninis marketingas“ padarè žinomą kaip mažų ir pradedančių įmonių sèkmingos veiklos rinkoje su mažu biudžetu filosofiją. Jis marketingo strategiją grindè netradiciniais marketingo kanalais, vartotojų artumu ir kantrybe. Sparčiai vystantis technologijoms, partizaninis marketingas igavo

3 Keršienè, V. Reklamos samprata ir etika. Reklamos rengimas ir projektavimas kompiuterinemis technologijomis. Vilnius: Atviros Lietuvos fondas, 2006.

4 Preimonas, P. Skaitmenines reklamos technologijos. Magistro baigiamasis darbas. Kaunas: Kauno technologijos universitetas, 2009.

5 Nufer, G. Guerilla marketing - innovative or parasitc marketing. Modern economy. 2013, 4: $1-4$.

6 Caliskan, G. Incidence of Guerrilla Marketing Practice in Small and Medium Sized Turkish Exporters. European journal of Economics and Political Studies. 2012, (1): 23-34. 
marketingo formą, šiomis dienomis dažniausiai taikomą rèmimo tikslais. Atsirado naujų marketingo formų, tokių kaip pasalos bei virusinis marketingas.

Pasak Kadeno ${ }^{7}$, partizaninis marketingas siekia tradicinių tikslų, tokių kaip pelnas ir džiaugsmas, netradiciniais metodais, t. y. investuojant energiją vietoj pinigų. Levisonas ${ }^{8}$ partizaninį marketingą apibrèžia kaip netradicinị marketingą, kuriuo siekiama gauti maksimalų rezultatą minimaliomis sąnaudomis.

Ali, Goriparthi ${ }^{9}$ teigia, kad partizaninis marketingas yra komunikacinis pranešimas netradiciniu būdu ir apibūdinamas kaip inovatyvi marketingo priemonè, nereikalaujanti didelių išlaidų. Partizaniniame marketinge pranešimas yra gaunamas asmeniškai.

Wannerio ${ }^{10}$ nuomone, partizaninis marketingas yra kūrybiška, netradicinè, nebrangi interaktyvi marketingo rūšis. Partizaninis marketingas buvo sukurtas ne ypač plačiai žinomiems prekių ženklams ir organizacijoms kaip mažo biudžeto alternatyva. Sèkmingos partizaninès reklamos kampanijos suteikia naudos tiek mažiems, tiek plačiai žinomiems prekès ženklams ir tai yra padaroma ịsimintinesniu būdu, negu ịstengia tradicinè reklama. Partizaninè reklama yra ideali smulkiesiems gamintojams, kurie negali daug lèšų skirti reklamai.

Partizaninis marketingas yra greitai auganti sritis. „Fortune 500“ kompanijos pradèjo integruoti partizaninị marketingą ị savo marketingo planus. Tuo laiku, kai tradicinès reklamos formos nebeveikè auditorijos, marketingo specialistai suvokè poreikị keisti savo rèmimo strategiją. Partizaninis marketingas yra nauja ir inovatyvi veikla pasiekti žmones netradicinèse vietose netikètais būdais.

Mughari ${ }^{11}$ teigia, kad pagrindinè partizaninio marketingo taktika būti nusistovejjusių reklamos metodų substitutu, pasižyminčiu inovacijomis ir kūrybiškumu.

Akivaizdu, kad dovanos sukelia teigiamas vartotojų emocijas, kurias rodo ne tik augantys pardavimo mastai, bet ir glaudesni įmonès ir vartotojų santykiai ${ }^{12}$.

Partizaninis marketingas yra marketingo strategija, kuri šiomis dienomis taikoma kaip marketingo komplekso elementas - rèmimas. Tai yra marketingo forma, kuri apima vartotoją reklamos požiūriu. Partizaninio marketingo kampanijos parodo kūrybingos idejos dinamiką neįprastais metodais vietose, kur reklama mažiausiai tikètina. Jos tikslas sujaudinti, sužavėti ir įkvejpti klientą. Patartina nekartoti partizaninių veiksmų, kurie nestebina, bet greičiau suerzina. Klasikinès marketingo komunikacijos per komercinę televi-

$7 \quad$ Kaden, R. J. Guerrilla marketing research: Marketing research techniques that can help any business make more money. London and Philadelphia: Kogan Page, 2007.

8 Levinson, J. C. Guerrilla creativity make your messages irresistible with the powers of memes. New York: Houghton Mifflin Company, 2001.

9 Ali, M.; Goriparthi, R. Guerrilla marketing- reaching the customer in an untraditional way. Asia Pacific Journal of Marketing \& Management Review. 2012 , 1 (3): 144-150.

10 Wanner, M. More Than the Consumer Eye Can See: Guerrilla Advertising From an Agency Standpoint. The Elon Journal of Undergraduate Research in Communications. 2011, 2(1): 103-109.

11 Mughari, A. M. Analysis of guerrilla and traditional marketing integration in improving the productivity oforganizational marketing in enterprises in Iran: A casestudy of Kaveh Industrial Estate in Iran. African Journal of Business Management. 2011, 5(3): 944-948.

12 Ay, C.; Unal, A. New marketing approachfor SMEs: Guerilla marketing. J. Manage. Econ. 2002, 9: 75-85. 
ziją, laikraščių priedus, radiją ir tiesioginiai laiškai daugiau nejaudina kliento. Partizaninis marketingas, virusinis marketingas ir iš lūpų ị lūpas marketingas yra idèjos, kurios padidina produkto paklausą, ypač per svarbiausią marketingo kanalą - internetą.

Pagrindinis partizaninio marketingo tikslas yra pritraukti kuo daugiau vartotojų minimaliomis sąnaudomis. Todèl partizaninio marketingo strategija yra pagrịsta fantazija, laisvumu ir lankstumu. Svarbiausios partizaninio marketingo dalys yra energija ir laikas.

1 lenteleje, sudarytoje remiantis Levinsonu ${ }^{13}$, lyginamas tradicinis ir partizaninis marketingas.

1 lentele. Tradicinio ir partizaninio marketingo palyginimas

\begin{tabular}{|c|c|c|}
\hline Kriterijai & Tradicinis marketingas & Partizaninis marketingas \\
\hline Investicijos & $\begin{array}{l}\text { Norint, kad prekè būtų } \\
\text { pardavinėjama tinkamai, } \\
\text { reikia investuoti pinigus }\end{array}$ & $\begin{array}{l}\text { Investuoti pinigus nèra būtina, geriau inves- } \\
\text { tuoti laiką, energiją, vaizduotę ir informaciją }\end{array}$ \\
\hline $\begin{array}{l}\text { Veiksmingumo } \\
\text { rodikliai }\end{array}$ & $\begin{array}{l}\text { Veiksmingumą atspindi par- } \\
\text { davimas, vartotojų atsakas ị } \\
\text { pasiūlą, interneto svetainès } \\
\text { lankomumas ar pirkèjų } \\
\text { srautas parduotuvejje }\end{array}$ & Svarbiausias skaičius - pelno dydis \\
\hline $\begin{array}{l}\text { Vartotojų } \\
\text { vertinimas }\end{array}$ & $\begin{array}{l}\text { Pagristas patirtimi ir ver- } \\
\text { tinimais }\end{array}$ & Remiasi psichologija \\
\hline $\begin{array}{l}\text { Verslo } \\
\text { plètojimas }\end{array}$ & $\begin{array}{l}\text { Vadovaujasi požiūriu, kad } \\
\text { verslą reikia plètoti arit- } \\
\text { metine progresija - kaskart } \\
\text { pridèti po vieną naują } \\
\text { klientą }\end{array}$ & $\begin{array}{l}\text { Verslą reikia plètoti geometrine progresija } \\
\text { - didinti kiekvieno sandorio apimtis, ị } \\
\text { kiekvieną prekybos su kiekvienu klientu ciklą } \\
\text { ịtraukti daugiau sandorių, išnaudoti kiekvieno } \\
\text { kliento rekomendacijų potencialą ir tuo pat } \\
\text { metu augti ịprastu senuoju būdu }\end{array}$ \\
\hline $\begin{array}{l}\text { Grịžtamasis } \\
\text { ryšys }\end{array}$ & $\begin{array}{l}\text { Veiksmai skirti pardavimui } \\
\text { ir pagrįsti prielaida, kad } \\
\text { marketingo procesas baigia- } \\
\text { mas, kai prekė yra parduota }\end{array}$ & $\begin{array}{l}\text { Propaguoja grịžtamaji ryši - nuolat bendrauja } \\
\text { su klientais, įsiklauso ị jų nuomonę }\end{array}$ \\
\hline Siekiamybė & Pinigai & Nauji ryšiai bei pelnas \\
\hline Auditorija & $\begin{array}{l}\text { Siekia perduoti žinią kuo } \\
\text { didesnei grupei žmonių - } \\
\text { kuo didesnè grupè, tuo } \\
\text { geriau. Informacija } \\
\text { skleidžiama plačiai } \\
\text { auditorijai }\end{array}$ & $\begin{array}{l}\text { Siekia perduoti žinią konkrečiam asmeniui, } \\
\text { o jei tai yra grupé - juo mažesnè, tuo geriau. } \\
\text { Siaurina tikslinę auditoriją }\end{array}$ \\
\hline
\end{tabular}

13 Levinson, J. C. Partizaninis marketingas. Vilnius: Ad Astra Marketing, 2009. 


\begin{tabular}{|l|l|l|}
\hline $\begin{array}{l}\text { Žinios } \\
\text { perteikimo } \\
\text { būdas }\end{array}$ & $\begin{array}{l}\text { Monologas. Tik perteikiama } \\
\text { žinia, neįtraukiant vartotojo }\end{array}$ & Dialogas - vartotojo įtraukimas ị procesą \\
\hline Priemonės & $\begin{array}{l}\text { Pripažístamos galingos } \\
\text { tradicinės: radijas, tele- } \\
\text { vizija, laikraščiai, žurnalai, } \\
\text { reklaminès medžiagos siun- } \\
\text { timas paštu, internetas }\end{array}$ & $\begin{array}{l}\text { Egzistuoja du šimtai kitų marketingo } \\
\text { priemonių ir dauguma jų yra nemokamos }\end{array}$ \\
\hline Reklamos vieta & $\begin{array}{l}\text { Tradicinèse reklamos } \\
\text { priemonėse }\end{array}$ & Priklauso nuo aplinkos \\
\hline Kaina & $\begin{array}{l}\text { Reklamos kaina paprastai } \\
\text { didelè }\end{array}$ & Reklamos kaina paprastai nedidelė \\
\hline
\end{tabular}

Šaltinis: sudaryta autorès remiantis Levinsonu (2009)

\section{Partizaninio marketingo priemonès}

Partizaninis marketingas vystytas daugeli metų, sukurta daug jo formų, kurios vadinamos ginklais. Šie ginklai remia pagrindinę partizaninio marketingo filosofiją, kuri pareikalavo kūrybiškumo, sąmoningo įkvejpimo. Partizaninis marketingas yra greitas būdas padaryti prekès ženklą žinomą. Atliekami paprastomis priemonėmis šie veiksmai privalo būti efektyvūs ir pritraukiantys tikslinès grupès dèmesị. Partizaninio marketingo ginklai skirstomi ị šias kategorijas:

Lauko ginklai. Lauko ginklai naudojami marketingo veiklą realizuojant viešosiose vietose. Jie sudomina žmones, kurie ne tiktai praeina pro šalį, bet taip pat domisi medijomis. Dienraštyje paskelbta veiklos ataskaita gali skatinti žmones kalbėti apie produktą. Sèkmingiausi lauko kategorijos ginklai yra partizaninè sensacija, aplinkos marketingas ir pasalos marketingas.

Nauji medijos ginklai. Naujos technologijos keičia mūsų gyvenimą, dažnai daro ji lengvesnị mobilaus telefono, interneto, neribotos informacijos ir apsisprendimo galimybių, kurios padeda prieiti prie pasaulinių išteklių tik paspaudus kompiuterio pelę, dèka.

Nedidelio biudžeto ginklai. Partizaninis marketingas tinkama priemonè mažoms ir vidutinio dydžio organizacijoms, kurios turi mažą marketingo biudžetą. Kaip 1980 metais pažymėjo Levinsonas, šios kompanijos nebūtinai patirs nuostoli palyginti su finansiškai stipriu konkurentu. Bet kadangi jų kapitalas yra mažas, svarbiausia jị panaudoti kuo efektyviau.

2 lentele. Partizaninio marketingo ginklai

\begin{tabular}{|l|l|}
\hline \multicolumn{1}{|c|}{$\begin{array}{c}\text { Partizaninio } \\
\text { marketingo ginklai }\end{array}$} & \multicolumn{1}{c|}{ Partizaninio marketingo priemonès } \\
\hline $\begin{array}{l}\text { Lauko ginklai } \\
\text { Aplinkos marketingas } \\
\text { Partizaninė sensacija } \\
\text { Pasalos marketingas }\end{array}$ & $\begin{array}{l}\text { Aplinkos marketingas. Aplinkos marketingo specialistai atrado būdą pranešti } \\
\text { apie savo prekès ženklą ịvykių, kurie pritraukia tūkstančius žiūrovų, metu. } \\
\text { Pavyzdžiui, „Pepsi“ kompanija reklamavo didelị „Pepsi“ butelị varžybų, } \\
\text { kurias rémé „Coca Cola“, vietoje }\end{array}$ \\
\hline
\end{tabular}




\begin{tabular}{|c|c|}
\hline & $\begin{array}{l}\text { Partizaniné sensacija. Partizaninė sensacija yra panaši ị pasalos marketingą. } \\
\text { Pasalos marketingas didelị dėmesị skiria reklamai neịprastose vietose. Svar- } \\
\text { biausia yra ne idejja, bet reklamos erdvė. Žmonės susiduria su reklama ten, } \\
\text { kur jie to nesitiki. Apskritai partizaninė sensacija yra naudojama labai ribotam } \\
\text { veiklų ir ịvykių skaičiui. } \\
\text { Pasalos marketingas. Terminas ,pasalos marketingas“ tapo gerai žinomas } \\
1990 \text { metais. Jis remiasi netradicine lauko reklama. Kai kiti marketingo spe- } \\
\text { cialistai reklamai renkasi dideles skelbimų lentas, pasalos reklama iškabinama } \\
\text { ant liuko dangčio, keliamojo krano. Pasalos reklama gali būti pranešimas met- } \\
\text { ro ekrane, ant picos dėžutės, nemokamo atviruko bare arba prekybos centro } \\
\text { vežimėlio rankenos. Reklama visada pateikiama neịprastai }\end{array}$ \\
\hline $\begin{array}{l}\text { Nauji medijos ginklai } \\
\text { Virusinis marketingas } \\
\text { Partizaninis mobilus }\end{array}$ & 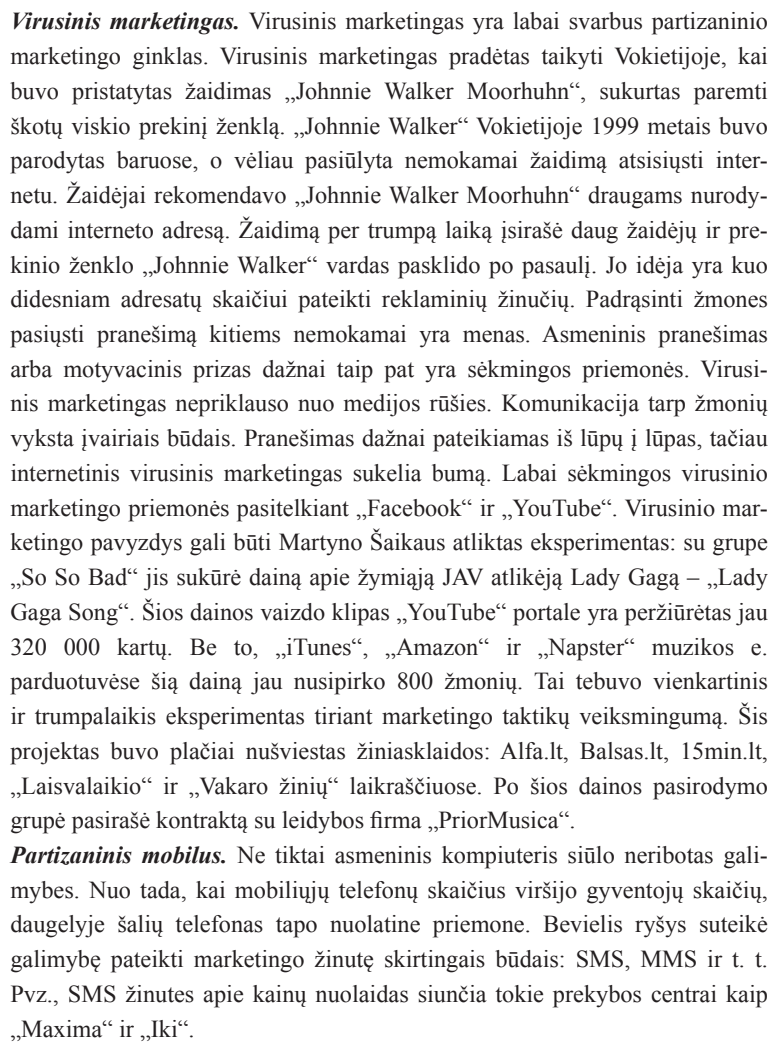 \\
\hline $\begin{array}{l}\text { Nedidelio biudžeto ginklai } \\
\text { Protingos idèjos mažoms ir } \\
\text { vidutinėms įmonèms }\end{array}$ & $\begin{array}{l}\text { Protingos idëjos mažoms ir vidutinèms ịmonèms. Partizaninis marketingas } \\
\text { orientuojasi ị vietinę kultūrą: socialinių tinklų, ritualų, normų, tradicijų. Pro- } \\
\text { tinga idèja, perteikta neįprastu būdu, pasieks tikslinę auditoriją }\end{array}$ \\
\hline
\end{tabular}


Egzistuoja 8 būdai, kaip galima užklupti žmogų nepasiruošusį, tuo momentu, toje vietoje, kur jis to mažiausiai tikisi. Šios technikos pasiteisina ir nevargina vartotojo.

Isiveržimas. İsiveržimo technika pasireiškia, kai atrandama nauja vieta reklamai ar informacijos pernešimui. Tam gali būti naudojamas bet koks objektas (automobilis, lèktuvas, žmogus, prekių vežimèlis prekybos centre, mobilus telefonas, bet kokia vieta, kur gali būti patrauktas dèmesys), koks tik gali būti prieinamas žmogui. Pagrindinis tikslas yra rasti vietą, kurios dar niekas nespejo panaudoti reklamai. Reklama gali suteikti galimybes originaliems, naujiems sprendimams.

Transformacija. Transformacijos technika patraukia demesį. Daiktas ne tik igauna neiprastas formas, bet taip pat yra labiau matomas. Kasdienybės daiktas yra panaudojamas kaip bendravimo priemonè. Tai gali būti žiebtuvèlis, rašiklis, batas, šviestuvas, mašina ir daugybẻ kitų îprastų dalykų, su kuriais žmogus nuolat susiduria. Transformuotas objektas patraukia demesị savo spalva, forma, dydžiu ${ }^{14}{ }^{15}$. Tradicinė lauko reklama yra dirbtiniu būdu primetama aplinkai, todèl pasiekiamas labai mažas efektyvumas, tuo tarpu transformacija îprastą pasaulio objektą paverčia kitokiu ir pateikia ji tokiose vietose ir tokiu laiku, kai to mažiausiai tikimasi. Norint pradèti kurti tokio pobūdžio reklamą reiktų nustoti matyti pasauli toki, koks jis iš tikro yra, o traktuoti jị kaip kūrybos ịkvejpeją. Kiekvieną objektą galima pasukti, padidinti, nuspalvinti ar kitaip kaip pakeisti ${ }^{16}$.

Instaliacija. Instaliacija neturi jokių rèmų ar taisyklių ir gali būti pagaminta iš bet kokios medžiagos, gali igauti bet kokią formą ar dydị ir būti bet kokioje aplinkoje. Instaliacija yra tinkama reklamai dèl keleto priežasčių. Pirma, instaliacija užima tam tikra vietą, ji igauna trimatę formą ir dèl šios priežasties jos neįmanoma nepastebėti. Antra, dèl savo trimatès formos ji gali būti gatvèje, ir žmonès su ja galès susidurti tiesiogiai. Instaliaciją galima paliesti, ant jos užlipti ar su ja žaisti. Instaliacija prekès ženklui suteikia trimati gyvenimą ir gali būti integruota ị gatvès gyvenimą ${ }^{17}$.

Iliuzija sujaukia mūsų supratimą apie tai, kas yra tikra, kas ne. Iliuzijos dẻka kai kurie nerealūs dalykai ar daiktai atrodo kaip tikri. Iliuzijos tikslas - priversti, nors sekundès dalį, mus patikèti, kad tai, ką matome, iš tikro vyksta arba egzistuoja. Ši technika patraukli tuo, kad stebètojui reikalingas laikas, kad jis suprastų, kur iliuzija yra paslëpta.

Isiskverbimas. Technologijų dẻka informacija žmogų pasiekia akimirksniu, tačiau patys žmonès yra nepakartojamas informacijos skleidejas. Planetoje yra apie 7 milijardai potencialių informacijos skleidèjų.

Jutimo. Palietus, paragavus, užuodus, išgirdus atsiminti daug lengviau. Tai yra daug efektyviau, nei pamatyti paveikslèlyje ar išgirsti telefonu. Jausmai sužadinami, kai su kuo nors susiduriame. Konkurencingoje aplinkoje, kur daug gamintojų reklamuoja panašius produktus, siekia parodyti, kaip jų produktas kvepia, kiek jis yra efektyvus, koks jis skanus ir nepakartojamas, tačiau dèl daugybès tokio pat pobūdžio reklamų ịtikinamumas paprasčiausiai dingsta.

Sąveikos. Prekès ženklai yra tarsi žmonès: pasižymi individualumu, perteikia elgesio manieras, vertybes. Santykiai tarp žmonių ir prekès ženklų yra prilyginami santykiams 
tarp žmonių. Jie susiduria su pasitikèjimo ir ištikimybès problemomis. Tradicinė reklama pagrịsta tuo, kad nèra grị̌žtamojo ryšio. Publika gautą žinutę gali perduoti toliau, tačiau jų reakcijos nepakeis transliuojamos žinios. Interaktyvaus bendravimo metu vartotojas yra aktyviai ịtraukiamas ị procesą, nes be vartotojo indèlio interaktyvus bendravimas yra kaip neužbaigtas produktas. Egzistuoja daugybẻ būdų, kuriais galima sukurti interaktyvų bendravimą: dideli renginiai, varžybos ar konkursai, prezentacijos turai, konferencijos, interaktyvūs žaidimai ir pan. Interaktyvaus bendravimo nauda ta, kad tai labiau issimenama.

Triukas. Dauguma triukų sukuriami turint tikslą pritraukti publiką. Be publikos tai būtų uždaras renginys, kurị stebètų vos keli žmonès. Toks renginys neliks nepastebėtas ne tik publikos, bet taip pat susilauks žiniasklaidos dèmesio.

Vienas iš pagrindinių partizaninio marketingo principų - partizaninis marketingas negali kainuoti brangiai, o išlaidos suprantamos kaip neefektyvus reklamos priemonių naudojimas ${ }^{18}$. Haigas ${ }^{19}$ pritaria, sakydamas, jog partizaninè rinkodara dažnai yra pigi. Levinsonas $^{20}$ teigia, jog partizaninis marketingas turi naudoti ir iprastas bei nebrangias priemones, tokias kaip: interneto svetainès, pristatymai, reklama ant marškinèlių, vizitinès kortelès.

\section{Empirinio tyrimo duomenų analizè}

Šis empirinis tyrimas buvo atliktas $2011 \mathrm{~m}$. vasario mènesį apklausiant Vilniaus Gedimino technikos universiteto studentus, studijuojančius pagal verslo vadybos, transporto vadybos, nekilnojamojo turto vadybos, statybos vadybos programas. Respondentams buvo išdalyta anketa, kurią sudare 19 uždaro tipo klausimų. Apklausoje dalyvavo 152 respondentai. 23 proc. respondentų sudarè iki 20 metų amžiaus grupę ir 77 proc. respondentų priklausė 20-25 metų amžiaus grupei. 51 proc. respondentų buvo vyrai ir 49 proc. respondentų sudarè moterys. 89 proc. respondentų mėnesinès pajamos buvo iki $1000 \mathrm{Lt}$ ir 7 proc. respondentų mènesinès pajamos sudarė $1000-1500$ Lt. 83 proc. respondentų tik studijavo ir 17 proc. apklausoje dalyvavusių respondentų teigè, kad jie dirba ir mokosi. 12,5 proc. dirbančių respondentų turèjo iki metų, 2,6 proc. - 1-5 metų ir 1,9 proc. respondentų - 5-10 metų darbo patirtị.

Siekiant išsiaiškinti, kokias partizaninio marketingo priemones respondentai laikytụ efektyviomis, buvo užduotas klausimas. Kaip matome iš 3 lentelès, kad efektyvios partizaninio marketingo priemonès yra internetas, visiškai sutinka 63 proc. respondentų, socialiniai tinklai - 47 proc. respondentų, reklaminès iškabos ir skelbimai - 28 proc. respondentų, nemokami seminarai - 24 proc., pavyzdžių dalijimas - 31 proc., vaizdinè reklama laikraščiuose - 18 proc. respondentų. Ne tokiomis efektyviomis partizaninio marketingo priemonėmis respondentai laiko telefoninị marketingą, asmeninius laiškus, geltonuosius puslapius, radijo reklamą. Taip pat buvo siekiama išsiaiškinti, ar partizaninis marketingas turètų pabrèžti kainos privalumą. 86 proc. respondentų teigè, kad turètų pabrèžti, o 14 proc. respondentų teigé, kad neturètų pabrèžti kainos privalumo.

19 Haig, M. Prekiu ženklų nesèkmès: Visa tiesa apie 100 didžiausiu visų laikų ženklodaros klaidų. Vilnius: Verslo žinios, 2009. 
3 lentele. Respondentų nuomonè apie partizaninio marketingo priemonių efektyvumą

\begin{tabular}{|l|c|c|c|c|c|c|c|c|c|c|}
\hline $\begin{array}{c}\text { Partizaninio marketingo } \\
\text { priemones }\end{array}$ & \multicolumn{2}{|c|}{$\begin{array}{c}\text { Visiškai } \\
\text { sutinku }\end{array}$} & \multicolumn{3}{c|}{ Sutinku } & \multicolumn{2}{c|}{$\begin{array}{c}\text { Nei sutinku, } \\
\text { nei nesutinku }\end{array}$} & \multicolumn{2}{c|}{ Nesutinku } & \multicolumn{2}{c|}{$\begin{array}{c}\text { Visiškai } \\
\text { nesutinku }\end{array}$} \\
\cline { 2 - 14 } & Dažn. & Proc. & Dažn. & Proc. & Dažn. & Proc. & Dažn. & Proc. & Dažn. & Proc. \\
\hline Internetas & 63 & 41 & 69 & 45 & 18 & 11,6 & 1 & 0,7 & 1 & 0,7 \\
\hline Socialiniai tinklai & 47 & 31 & 62 & 41 & 37 & 24 & 4 & 3 & 2 & 1 \\
\hline Virusinis marketingas & 8 & 5 & 32 & 21 & 78 & 51 & 23 & 15 & 11 & 7 \\
\hline $\begin{array}{l}\text { Reklamines iškabos ir } \\
\text { skelbimai }\end{array}$ & 28 & 18 & 62 & 41 & 59 & 39 & 11 & 7 & 2 & 1 \\
\hline Brošiuros & 12 & 8 & 49 & 32 & 60 & 39 & 21 & 14 & 10 & 7 \\
\hline Telefoninis marketingas & 6 & 4 & 32 & 21 & 59 & 39 & 41 & 27 & 14 & 9 \\
\hline Reklaminiai suvenyrai & 15 & 10 & 54 & 36 & 49 & 32 & 19 & 13 & 5 & 3 \\
\hline Viešieji ryšiai & 14 & 9 & 59 & 39 & 61 & 40 & 13 & 9 & 5 & 3 \\
\hline Skelbimų lentos & 17 & 11 & 56 & 37 & 50 & 33 & 26 & 17 & 3 & 2 \\
\hline Geltonieji puslapiai & 9 & 6 & 39 & 26 & 60 & 39 & 35 & 23 & 9 & 6 \\
\hline $\begin{array}{l}\text { Vaizdine reklama } \\
\text { laikraščiuose }\end{array}$ & 18 & 12 & 70 & 46 & 44 & 29 & 16 & 11 & 4 & 3 \\
\hline Radijo reklama & 16 & 11 & 67 & 44 & 60 & 40 & 16 & 11 & 3 & 2 \\
\hline Nemokami seminarai & 24 & 16 & 47 & 31 & 54 & 36 & 18 & 12 & 9 & 6 \\
\hline Viešieji ryšiai & 14 & 9 & 56 & 37 & 64 & 42 & 15 & 10 & 3 & 2 \\
\hline Reklaminiai suvenyrai & 14 & 9 & 56 & 37 & 55 & 36 & 25 & 16 & 2 & 1 \\
\hline Pavyzdžiu dalijimas & 31 & 20 & 58 & 38 & 49 & 32 & 12 & 8 & 2 & 1 \\
\hline Asmeniniai laiškai & 18 & 12 & 32 & 21 & 50 & 33 & 34 & 22 & 18 & 12 \\
\hline
\end{tabular}

Šaltinis: sudaryta autorès

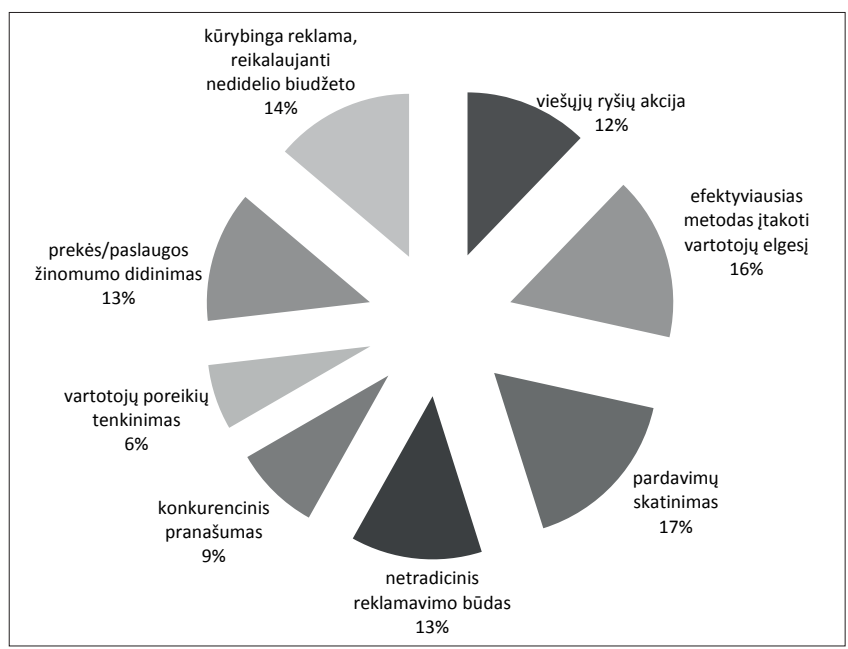

1 pav. Respondentų atsakymų ị klausimą „Kas laikoma partizaniniu marketingu?“ pasiskirstymas (proc.) 
Respondentams buvo užduotas klausimas, ką jie laiko partizaniniu marketingu. 30 proc. respondentų teigè, kad tai yra viešųjų ryšių akcija, 40 proc. - efektyviausias metodas daryti įtaką vartotojų elgesiui, 41 proc. - pardavimo skatinimas, 32 proc. netradicinis reklamavimo būdas, 21 proc. - konkurencinis pranašumas, 16 proc. - vartotojų poreikių tenkinimas, 32 proc. - prekès / paslaugos žinomumo didinimas, 34 proc. - kūrybiška reklama, reikalaujanti nedidelio biudžeto (žr. 1 pav.).

Respondentų paklausus, kokie yra partizaninio marketingo tikslai, dauguma respondentų teigé, kad tai yra pardavimų didinimas - 60 proc., atkreipimas dèmesio ị esamus ir potencialius klientus - 44 proc., konkurencinio pranašumo igijimas - 29 proc., prekès / paslaugos kainos privalumų pabrèžimas - 28 proc., pelno didinimas mažinant kainas - 32 proc. respondentų. Tik 19 proc. respondentų teigè, kad vienas iš partizaninio marketingo tikslų galètų būti konkurentų silpninimas (žr. 2 pav.).

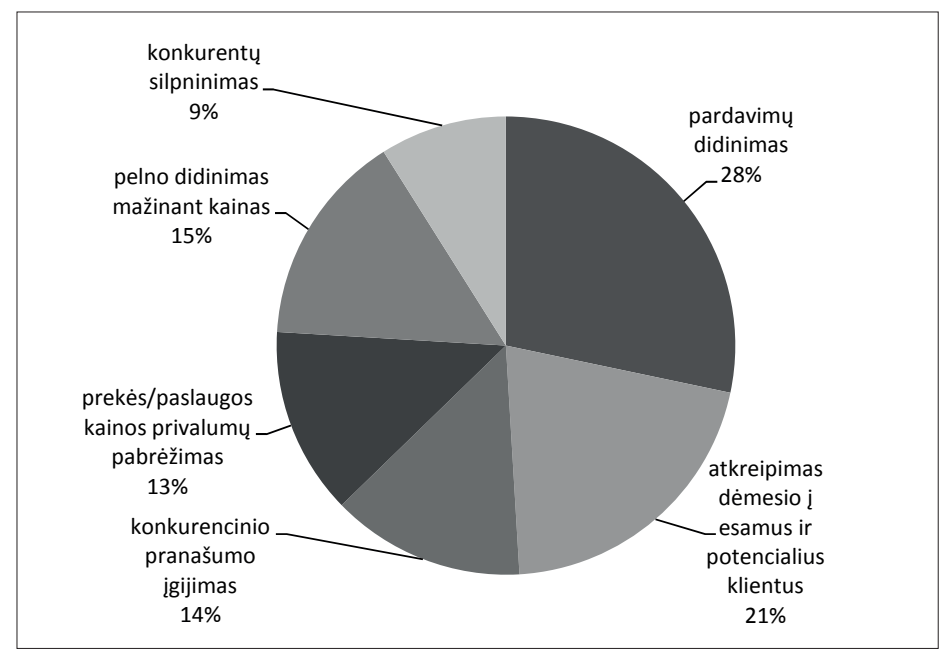

2 pav. Partizaninio marketingo tikslai (proc.)

Respondentų taip pat buvo klausiama, ką reikètų pabrèžti partizaniniu marketingu. 51 proc. respondentų teigè, kad prekę ar paslaugą, 39 proc. - prekès kokybę, 17 proc. pasirinkimą, 19 proc. - patogumą, 8 proc. - aptarnavimą. I klausimą, ar partizaninis marketingas skirtas susigrumti su konkurentais, 72 proc. respondentų teigé, kad taip, ir 28 proc. respondentų pažymėjo, kad ne. Kita svarbi informavimo priemonè, kuria yra naudojamasi, yra naujienlaiškis. Taigi, ị klausimą, ar skaito įmonès naujienlaiškius, 45 proc. respondentų atsakè teigiamai ir 55 proc. teigè, kad neskaito. Siekiant išsiaiškinti, kas yra svarbu taikant partizaninị marketingą, buvo užduotas klausimas apie reklamos priemones.

Kaip matyti, svarbiausiais veiksniais respondentai laiko reklamos ísimintinumą (55 proc.), lengvai suprantamą reklamą (56 proc.), vartotojo mintis pastebejjus žinutę. 
Pasak respondentų, dažniausiai jie reklamą pastebi televizijoje (67 proc.), internete (57 proc.), lauke (33 proc.). Rečiau reklama pastebima radijuje (22 proc.), spaudoje (29 proc.). Vadinasi, reklamuotis labiausiai, pasak respondentų, būtų tikslinga per televiziją arba internetą (žr. 3 pav.)

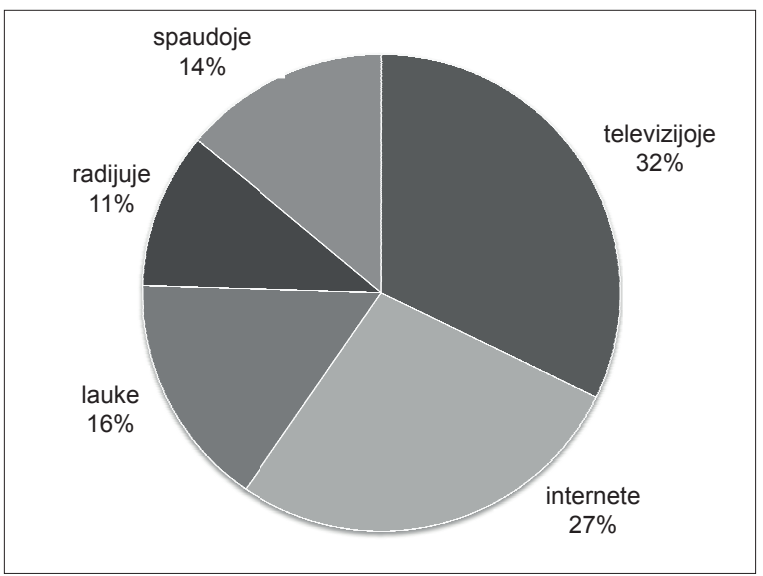

3 pav. Reklamos pastebimumas (proc.)

Siekiant išsiaiškinti, kokia reklamine žinutè respondentams patinka, buvo užduotas klausimas. Kaip matyti iš 4 lentelès, kad reklaminė žinutè turi turèti siurprizo elementų, visiškai pritaria, 45 proc. respondentų, 54 proc. - būti netradicinè, 53 proc. - būti kiek humoristinè, 24 proc. - vaizduoti realią buitinę situaciją.

4 lentelè. Respondentų atsakymai ị klausimą, ar Jums patinka reklaminè žinutė

\begin{tabular}{|c|c|c|c|c|c|c|c|c|c|c|}
\hline \multirow[t]{2}{*}{$\begin{array}{c}\text { Patinkančios reklaminès } \\
\text { žinutès savybès }\end{array}$} & \multicolumn{2}{|c|}{$\begin{array}{l}\text { Visiškai } \\
\text { pritariu }\end{array}$} & \multicolumn{2}{|c|}{ Pritariu } & \multicolumn{2}{|c|}{$\begin{array}{l}\text { Nei pritariu, } \\
\text { nei nepritariu }\end{array}$} & \multicolumn{2}{|c|}{ Nepritariu } & \multicolumn{2}{|c|}{$\begin{array}{l}\text { Visiškai } \\
\text { nepritariu }\end{array}$} \\
\hline & Dažn. & Proc. & Dažn. & Proc. & Dažn. & Proc. & Dažn. & Proc. & Dažn. & Proc. \\
\hline Turèti siurprizo elementų & 45 & 30 & 53 & 35 & 40 & 26 & 9 & 6 & 5 & 4 \\
\hline Būti netradicinè & 54 & 36 & 67 & 44 & 23 & 15 & 4 & 3 & 4 & 3 \\
\hline Būti aktuali & 69 & 45 & 64 & 42 & 19 & 13 & 44 & 29 & - & - \\
\hline Būti kiek humoristinė & 53 & 35 & 49 & 32 & 44 & 29 & 3 & 2 & 3 & 2 \\
\hline Vaizduoti įžymius žmones & 5 & 3 & 20 & 13 & 63 & 41 & 36 & 24 & 38 & 25 \\
\hline $\begin{array}{l}\text { Vaizduoti realią buitinę } \\
\text { situaciją }\end{array}$ & 24 & 16 & 45 & 30 & 66 & 43 & 10 & 7 & 7 & 5 \\
\hline
\end{tabular}

Šaltinis: sudaryta autorès 


\section{Išvados}

Partizaninis marketingas yra mažų išlaidų ịvairovè, didelio poveikio marketingo priemonès, kurios leidžia mažoms organizacijoms ir asmenims veikti kaip didelèms organizacijoms. Partizaninio marketingo veikimo metodai, lengvai ịsisavinamų marketingo ginklų arsenalas leidžia mažoms ir vidutinėms įmonėms veiksmingai konkuruoti net ir su daug lèšų rinkodarai išleidžiančiais verslo banginiais. Partizaninis marketingas - tai nuostata ir kartu verslo praktika, ịgalinanti įmones mažomis sąnaudomis uždirbti didelị pelną.

Verslo „partizanu“ vadinamas asmuo, dažniausiai smulkiojo verslo savininkas, kuris naudoja daug nebrangių rinkodaros priemonių bei rinkodaros triukų savo įmonès paslaugoms reklamuoti ir pelnui padidinti. Versle egzistuoja trys elementai - greitis, kokybė, kaina - iš kurių tegalima pasirinkti du. Jei norite kokybiško darbo greitai - sumokèsite daug; jei norite greitai ir pigiai - darbas bus nekokybiškas. Verslo „partizanas“ renkasi kokybę ir kainą, t. y. investuoja laiką, sveiką protą, energiją ir tokiu būdu sukuria kokybišką prekę, daug už ją nesumokėdamas.

Partizaninè reklama gali kelti pavojų. Pavyzdžiui, partizaninė reklama viduryje kelio arba ant autobusų, privačių automobilių gali sukelti eismo nelaimę.

Partizaninis marketingas igyja galios per originalumą ir inovacijas. Jis nenaudoja brangių priemonių, tokių kaip televizija. Jis labiau remiasi inovatyviomis priemonemis. Partizaninio marketingo priemonès mokslineje literatūroje klasifikuojamos ị lauko ginklus, nedidelio biudžeto ginklus, naujus medijos ginklus.

Apklausos rezultatai parode், kad didžioji dauguma respondentų partizaninị marketingą laiko viešųjų ryšių akcija, efektyviausiu metodu paveikti vartotojų elgesį, pardavimo skatinimu, netradiciniu reklamavimo būdu, konkurenciniu pranašumu, vartotojų poreikių tenkinimu, prekès / paslaugos žinomumo didinimu, netradiciniu reklamavimo būdu, kūrybiška reklama, reikalaujančia nedidelio biudžeto. Efektyviomis partizaninio marketingo priemonėmis respondentai laiko internetą, socialinius tinklus, reklamines iškabas ir skelbimus, nemokamus seminarus, pavyzdžių dalijimą, vaizdinę reklamą laikraščiuose. Partizaninio marketingo tikslai, respondentų nuomone, yra pardavimo didinimas, atkreipimas dėmesio ị esamus ir potencialius klientus, konkurencinio pranašumo ịgijimas, prekès / paslaugos kainos privalumų pabréžimas, pelno didinimas mažinant kainas, konkurentų silpninimas. Pasak respondentų, dažniausiai jie reklamą pastebi televizijoje, internete, lauko reklamoje. Rečiau reklama pastebima radijuje, spaudoje. Todèl reklamuojantis patartina labiau išnaudoti televiziją ir internetą.

\section{Literatūra}

Ali, M.; Goriparthi, R. Guerrilla marketing- reaching the customer in an untraditional way. Asia Pacific Journal of Marketing \& Management Review. 2012, 1(3): 144-150.
Ay, C.; Unal, A. New marketing approachfor SMEs: Guerilla marketing. J. Manage. Econ. 2002, 9: 75-85.

Caliskan, G. Incidence of Guerrilla Marketing Practice in Small and Medium Sized Turkish Exporters. 
European Journal of Economics and Political Studies. 2012, (1): 23-34.

Canan, Ay. Pinar Aytekin and Sinan Nardali. Guerrilla Marketing Communication Tools and Ethical Problems in Guerilla Advertising. American Journal of Economics and Business Administration. 2010, 2 (3): 280-286.

Išoraitè, M. Guerilla marketing strategy realization assumptions. 6th International Scientific Conference May 13-14, Lithuania Business and management 2010 Selected papers. Vilnius, 2010, p. 382-389.

Haig, M. Prekiuzženklų nesèkmès: Visa tiesa apie 100 didžiausių visu laikų ženklodaros klaidų. Vilnius: Verslo žinios, 2009.

Himpe, T. Advertising is dead. Long life advertising! London: Thames \& Hudson, 2006.

Kaden, R. J. Guerrilla marketing research: Marketing research techniques that can help any business make more money. London and Philadelphia: Kogan Page, 2007.

Keršienè, V. Reklamos samprata ir etika. Reklamos rengimas ir projektavimas kompiuterinemis technologijomis. Vilnius: Atviros Lietuvos fondas, 2006.

Kotler, P. New Marketing Lessons. 1st Edn., Cem Ofset, 2005.

Levinson, J . C. Guerilla Advertising: CostEffective Techniques for Small-Business Success. 1st Edn., Houghton Mifflin Company, USA, 1994.
Levinson, J. C. Guerilla Marketing. 3rd Edn., Mariner Books, USA, 1998.

Levinson, J. C. Guerrilla creativity make your messages irresistible with the powers of memes. New York: Houghton Mifflin Company, 2001.

Levinson, J. C. Partizaninis marketingas. Vilnius: Ad Astra Marketing, 2009.

Mughari, A. M. Analysis of guerrilla and traditional marketing integration in improving the productivity oforganizational marketing in enterprises in Iran: A casestudy of Kaveh Industrial Estate in Iran. African Journal of Business Management. 2011, 5(3): 944-948.

Nufer, G. Guerilla marketing - innovative or parasitc marketing. Modern economy. 2013, 4: 1-4.

Wanner, M. More Than the Consumer Eye Can See: Guerrilla Advertising From an Agency Standpoint. The Elon Journal of Undergraduate Research in Communications. 2011, 2(1): 103-109.

Preimonas, P. Skaitmeninés reklamos technologijos. Magistro baigiamasis darbas. Kaunas: Kauno technologijos universitetas, 2009.

Reyburn, D. Ambient Advertising. Marketing Health Services. 2010, 30(1): 8-11.

Ries, A.; Trout, J. Marketing Generalstabsmäßig. Hamburg, 1986.

<http://www.marketingoguru.lt/seminarai/mg2.pdf-> [žiūrèta 2013-11-06]. 


\title{
GUERILLA MARKETING TOOLS RESEARCH
}

\author{
Margarita Išoraitè
}

Vilnius College, Lithuania

Summary. The article analyzes the theoretical aspects of guerrilla marketing, guerrilla marketing tools and respondent's opinion about the efficiency of guerrilla marketing tools. Guerrilla marketing tactics are available to any small organization to compete with larger organizations. Small organizations are considered to be closer to clients and pro-active. Guerrilla marketing acts with less money, but requires more mental work. The main goal of guerrilla marketing is to attract the greatest attention of consumers at minimum cost. Brand strength plays particular attention. Guerrilla marketing strategy is based on fantasy, freedom and flexibility. The main guerrilla marketing (tools?) are energy and time. Guerrilla marketing is a marketing strategy, which uses an element of the marketing mix - promotion. Guerrilla marketing company shows the dynamics of creative ideas for unusual methods of places. Its purpose is to delight and inspire the client. Guerrilla marketing innovation and entrepreneurial spirit is most evident in the activities of business. Uniquely designed advertising support focuses not only on transmitting a message to the consumer, but also on ensuring that their message will remain in memory longer. It is important to increase efficiency. The survey results showed that the vast majority of respondents consider guerrilla marketing as public relations campaign, the most effective method to influence consumer's behaviour, sales promotion, non-traditional forms of advertising, competitive advantage, product/service awareness-raising, non-traditional forms of advertising, creative advertising, which requires a small budget. Effective guerrilla marketing forms are the Internet, social networks, advertisings signs, free seminars and distributions of samples.

Keywords: guerrilla marketing, viral marketing, marketing, guerrilla marketing tools.

Margarita Išoraitė, Vilniaus kolegijos Verslo vadybos fakulteto Prekybos katedros docentė, socialinių mokslų daktarè. Mokslinių tyrinejjimų kryptys: marketingo valdymas, strateginis marketingas.

Margarita Išoraitè, Vilnius College, Faculty of Business Management, Commerce, Department, associated professor, doctor of Social Sciences. Research interest: marketing management, strategic marketing. 